\title{
Assessing Transportation Infrastructure Impacts on Rangelands: Test of a Standard Rangeland Assessment Protocol
}

\author{
Michael C. Duniway, ${ }^{1}$ Jeffrey E. Herrick, ${ }^{1}$ David A. Pyke, ${ }^{2}$ and David Toledo P. ${ }^{3}$
}

Authors are ${ }^{1}$ Research Soil Scientists, US Department of Agriculture-Agricultural Research Service Jornada Experimental Range, PO Box 30003 , MSC 3JER, Las Cruces, NM 88003, USA; ${ }^{2}$ Research Plant Ecologist, US Geological Survey, Forest and Rangeland Ecosystem Science Center, 3200 SW Jefferson Way, Corvallis, OR 97331, USA; and ${ }^{3}$ Graduate student, Texas A\&M University, Department of Ecosystem Science and Management, College Station, TX 77843, USA.

\begin{abstract}
Linear disturbances associated with on- and off-road vehicle use on rangelands has increased dramatically throughout the world in recent decades. This increase is due to a variety of factors including increased availability of all-terrain vehicles, infrastructure development (oil, gas, renewable energy, and ex-urban), and recreational activities. In addition to the direct impacts of road development, the presence and use of roads may alter resilience of adjoining areas through indirect effects such as altered site hydrologic and eolian processes, invasive seed dispersal, and sediment transport. There are few standardized methods for assessing impacts of transportation-related land-use activities on soils and vegetation in arid and semi-arid rangelands. Interpreting Indicators of Rangeland Health (IIRH) is an internationally accepted qualitative assessment that is applied widely to rangelands. We tested the sensitivity of IIRH to impacts of roads, trails, and pipelines on adjacent lands by surveying plots at three distances from these linear disturbances. We performed tests at 16 randomly selected sites in each of three ecosystems (Northern High Plains, Colorado Plateau, and Chihuahuan Desert) for a total of 208 evaluation plots. We also evaluated the repeatability of IIRH when applied to road-related disturbance gradients. Finally, we tested extent of correlations between IIRH plot attribute departure classes and trends in a suite of quantitative indicators. Results indicated that the IIRH technique is sensitive to direct and indirect impacts of transportation activities with greater departure from reference condition near disturbances than far from disturbances. Trends in degradation of ecological processes detected with qualitative assessments were highly correlated with quantitative data. Qualitative and quantitative assessments employed in this study can be used to assess impacts of transportation features at the plot scale. Through integration with remote sensing technologies, these methods could also potentially be used to assess cumulative impacts of transportation networks at the landscape scale.
\end{abstract}

\section{Resumen}

Los disturbios lineales asociados con el uso de vehículos (incluyendo vehículos todoterreno) en áreas naturales han incrementado dramáticamente en todo el mundo en décadas recientes. Esto ha sido causado por una variedad de factores que incluyen el aumento en la disponibilidad de vehículos todoterreno, la infraestructura asociada con el desarrollo (petróleo, gas, energía renovable, desarrollo ex-urbano) y actividades recreacionales. En adición a los impactos directos, la presencia y uso de estas calles puede alterar la resiliencia de áreas adyacentes a través de efectos indirectos tales como alteraciones en los procesos hidrológicos y eólicos del sitio, en la dispersión de semillas de especies invasoras, y en el transporte de sedimentos. Hay pocos métodos estandarizados para evaluar los impactos de las actividades de transporte sobre el suelo y la vegetación en pastizales áridos y semiáridos. La Interpretación de Indicadores para la Salud de los Pastizales (IIRH) es un método cualitativo que ha sido ampliamente utilizado y que ya está aceptado a nivel internacional para la evaluación de pastizales. Evaluamos la sensibilidad de IIRH a los impactos de calles, caminos y ductos en áreas adyacentes a estos disturbios, muestreando parcelas ubicadas a tres distancias de estos disturbios lineales. Hicimos esta evaluación en 16 sitios seleccionados al azar dentro de cada uno de 3 ecosistemas (las Planicies Altas del Norte, la Meseta del Colorado, y el Desierto Chihuahuense) para un total de 208 parcelas de muestreo. También evaluamos la repetibilidad de IIRH cuando es aplicado a gradientes de disturbios causados por calles y caminos. Para finalizar, examinamos qué tan correlacionadas estuvieron las evaluaciones de atributos de las parcelas con las tendencias de un grupo de indicadores cuantitativos. Los resultados indicaron que la técnica de IIRH es sensible a impactos directos e indirectos de las actividades de transporte y que la desviación a partir del estado de referencia disminuye a medida que la distancia al disturbio aumenta. Las tendencias en la degradación de procesos ecológicos detectadas con las evaluaciones cualitativas estuvieron altamente correlacionadas con los datos cuantitativos. Las evaluaciones cuantitativas y cualitativas utilizadas en este estudio pueden ser utilizadas para examinar los impactos de la infraestructura de transporte a la escala de la parcela. Por medio de la integración tecnológica de sensores remotos, estos métodos también podrían ser utilizados para examinar los impactos acumulativos de redes de transporte a la escala del paisaje.

Key Words: disturbance, indicators, off-highway vehicles, oil and gas, rangeland health, roads

This work was funded by the Bureau of Land Management.

Any use of trade, product, or firm names is for descriptive purposes only and does not imply endorsement by the US Government.

Correspondence: Michael Duniway, US Dept of Agriculture-Agricultural Research Service Jornada Experimental Range, PO Box 30003, MSC 3JER, Las Cruces, NM 88003, USA. Email: mduniway@nmsu.edu

Manuscript received 22 November 2009; manuscript accepted 27 May 2010. 


\section{INTRODUCTION}

The amount and extent of vehicle activity in rangelands of the world have rapidly increased in recent decades. This increase is due to a variety of factors including availability of all terrain vehicles, recreational activities, oil and gas development, and ex-urban development (Hansen et al. 2002; Williams 2003; Brown et al. 2005; Vias and Carruthers 2005; Watts et al. 2007; Leu et al. 2008). Development of renewable energy sources, including wind and solar, is predicted to lead to additional road development in rangelands. Wind power requires a road to each windmill, and both wind and solar power will require development of thousands of miles of new transmission lines, each of which requires a service road. Although numerous studies and review papers have investigated direct changes to soils and vegetation due to road and vehicle disturbances (see review by Forman and Alexander 1998), there is little guidance on how to assess and monitor roads and adjacent areas to detect changes in vegetation and soils due to vehicle-related disturbances. For effective local to landscape scale management of transportation networks, assessment and monitoring programs are needed that capture how roads, trails, and other development activities directly and indirectly alter ecological function (Treweek et al. 1998).

Direct impacts of transportation networks on soils and vegetation vary with road type (Brooks and Lair 2005). Direct impacts of improved local roads are not generally studied. Impacts on soil quality and vegetation communities are obvious and extreme, including total removal of surface soil horizons and all vegetation. Direct impacts of planned or unplanned trails (that are established by use and not engineered) are typically less certain and therefore have been more extensively studied. Impacts to soils include compaction and rutting of surface soils (Webb 1983; Lei 2004) resulting in decreased infiltration (Thurow et al. 1993) and increased soil erosion (Iverson 1980). Additionally, disturbance of soil surfaces can break up biological soil crusts and other soil stabilizing aggregates, resulting in increased erosion by both wind and water (Belnap 1995; Belnap and Gillette 1997; Li et al. 2009). Impacts on vegetation include mortality of all or part of the plant from vehicles crushing and reducing soil water and nutrients through soil degradation and loss (Lovich and Bainbridge 1999). Shifts in plant community composition can also occur in roads and trails due to the variation in speciesspecific resilience from repeated disturbance (Thurow et al. 1993; Yorks et al. 1997; Bolling and Walker 2000) and the introduction of exotic species (Lovich and Bainbridge 1999; Gelbard and Belnap 2003).

There is considerably less information on when and how far impacts on vegetation and soils extend beyond areas directly contacted by vehicles. Most of the literature on indirect impacts of roads and trails (hereafter referred to as roads) investigates impacts on wildlife such as habitat fragmentation (Theobald et al. 1997) and noise or visual disturbance (Reijnen et al. 1997). However, the presence and use of these roads has potentially altered the resilience of soils and vegetation in adjoining areas through indirect effects such as altered site hydrologic and eolian processes (Belnap and Gillette 1997; Li et al. 2009), invasive seed dispersal (Abella et al. 2009), and sediment transport (Belnap 1995; Gellis 1996; Fang et al. 2002; Ziegler et al. 2002; Fuchs et al. 2003; Grismer 2007). Furthermore, these indirect impacts will also vary with road type (planned or unplanned). For example, engineered roads may minimize erosion processes that impact road function but inadvertently cause greater alteration of landscape hydrologic processes (Forman and Alexander 1998). Conversely, unplanned roads may have less impact on landscapes when evaluated individually but, because they often occur as fairly dense networks, may have greater impact on some landscapes when evaluated cumulatively (Brooks and Lair 2005).

Secondary, unsurfaced roads and trails make up the majority of roads in rural areas of the western United States (Watts et al. 2007; Leu et al. 2008). Although there is a poor understanding of rate of change in infrastructure development in rural areas (Theobald 2001), secondary road types associated with energy development and recreational activities likely represent the majority of new roads in this area. In the Powder River Basin of northeastern Wyoming alone, the current Bureau of Land Management (BLM) management plan allows for establishment of an additional 17754 miles $(28572 \mathrm{~km})$ of roads and 26157 miles $(42096 \mathrm{~km})$ of pipelines and overhead electric lines to support energy development activities between 2003 and 2013 (BLM 2003, p. 2-18). The number of off-road vehicles owned in the United States almost tripled between 1993 and 2003, with rates of participation in off-highway vehicle recreation highest in the intermountain west (27\% of persons 16 and older in Arizona, Colorado, Idaho, Montana, Nevada, New Mexico, Utah, and Wyoming; Cordell et al. 2005). Effective management of ecosystem impacts associated with energy and recreation activities requires assessment and monitoring systems capable of detecting where on the landscape impacts are occurring and how those impacts are altering ecosystem function. Assessment and monitoring data from such a system can then help inform land managers what actions are necessary for mitigation of past and minimizing impacts of future activities.

The general goal of this study was to test the applicability of existing assessment and monitoring techniques for detecting impacts on rangelands due to roads, trails, and pipelines. If applicable, these techniques could then be used in conjunction with existing route inventory (Graves et al. 2006) and usage information to develop comprehensive travel management plans. Additionally, if similar methods could be employed to assess and monitor impacts of roads as are currently used in nonroad areas, results could be integrated into general resource management plans. The Interpreting Indicators of Rangeland Health (IIRH) protocol (Pellant et al. 2005) was selected for this study because it has a demonstrated ability to assess ecosystem processes, including soil nutrients, erosion, and moisture-related processes, and is widely applied by two US agencies primarily responsible for rangeland assessment and monitoring (Natural Resource Conservation Service [NRCS] and BLM). Such qualitative techniques are particularly useful because they can provide relatively rapid assessments of a wide range of ecological processes that are difficult to measure but necessary for understanding proximity to ecological thresholds (Bestelmeyer 2006). IIRH assessments done across a landscape can provide a snapshot of how ecological processes are affecting ecosystem resilience (Miller 2008) and restoration potential (King and Hobbs 2006). 


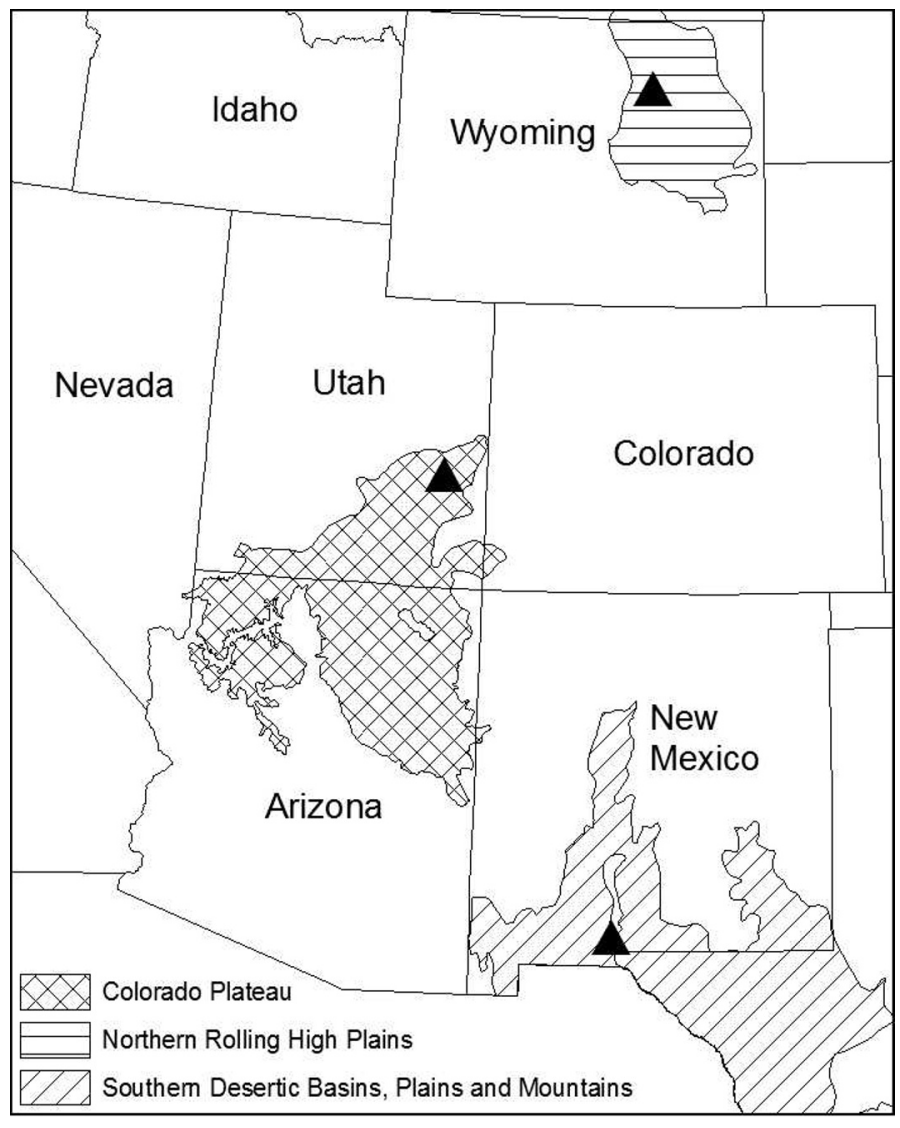

Figure 1. Study area locations (black triangles) and Natural Resources Conservation Service [NRCS] Major Land Resource Areas (USDANRCS 2002).

This study was designed to address three objectives: 1 ) assess the sensitivity of IIRH attributes and indicators to impacts on rangelands caused by roads; 2 ) test if variability among IIRH observer attribute ratings in road-related disturbance gradients limits the protocol's potential to detect these impacts; and 3) assess the extent to which trends in IIRH attribute departure classes for plots located in a disturbance gradient are correlated with trends in a suite of quantitative indicators. We use the results to illustrate how IIRH can be used to determine which ecosystem processes are impacted most and discuss how coupled qualitative-quantitative measures can be used to select monitoring indicators most likely to detect impacts of roads and other linear development infrastructure on rangeland ecosystem properties. Finally, we provide guidance for application of IIRH to rangelands impacted by roads.

\section{MATERIALS AND METHODS}

\section{General Approach}

The study was conducted in three semiarid regions of the western United States: the Northern High Plains (Wyoming), the Colorado Plateau (Utah), and the Chihuahuan Desert (New Mexico; Fig. 1; Table 1). Coupled qualitative and quantitative protocols were applied across a broad spectrum of impacts caused by common road and trail types in the three regions. The study was conducted at four sites for each of four road types in each of the three regions for a total of 48 sites sampled. Each site was divided into two to six plots, depending on disturbance type (Fig. 2). The intensive plot design used in this study was intended to test sensitivity of methods; we expect that a simpler, more practical plot design would be used for implementation of these methods in an assessment or monitoring program. We did not have the resources to address our objectives on all types of linear disturbances that occur on rangelands or on multiple ecological sites in each region (US Department of Agriculture [USDA]-NRCS 2003). Therefore, we limited our research to one ecological site per region, and to disturbance types that were of concern to land managers and that posed the most difficulty in adapting existing assessment and monitoring techniques: unpaved, fairly narrow, linear roads, trails, and pipelines (Tables 1 and 2).

\section{Study Locations}

A study area was selected within each region where road development and/or off-road vehicle activity was a substantial concern of local BLM and where a variety of road types was present (Table 1). The Wyoming study area was located in the Powder River Basin, which is underlain by vast energy reserves and has been the focus of recent intense coal bed natural gas exploration and well development. The Utah study area has been the subject of repeated seismic exploration, has several active natural gas wells, and is the focus of intense recreational off-road vehicle activity. The New Mexico study area is bisected by natural gas pipelines and has extensive networks of unregulated recreational off-road vehicle trails.

\section{Site and Plot Selection}

To select sites within study areas, we used a random sampling design stratified by qualitatively assessed road impact determined using recent high-resolution aerial imagery. From our observations, it appears that the most severe road impacts are often spatially concentrated and not evenly distributed across a road network. This stratification approach was used to ensure that half the study sites included problem road segments. To select areas for high-resolution aerial photography acquisition (three $2.4-\mathrm{km}$ by $1.5-\mathrm{km}$ rectangles in each study area, size, and number determined by width of aerial image footprint and cost limitations), we surveyed existing road, ownership, imagery, and soil maps to find locations on public land that maximized the length of linear features of interest on the chosen ecological site. We acquired color and color infrared aerial photos (1:8 000) of each study area prior to field work (August 2007 in Wyoming and October 2007 in Utah and New Mexico). Photos were scanned at a $10-\mathrm{cm}$ ground sampling distance (10$\mathrm{cm}$ pixels), georeferenced, and orthorectified (see Fig. S1, available at http://dx.doi.org/10.2111/REM-D-09-00176.sf1).

Within the aerial image of each study area, we created a stratified-random sample of road sites by manually digitizing roads on recent Digital Orthophoto Quarter-Quadrangle imagery (DOQQ, 1:12 000; 2006 in Wyoming and Utah, and 2005 in New Mexico), classifying them by road type (Table 2), dividing them into $30-\mathrm{m}$ segments, and assigning a random number to each segment. DOQQ imagery was used instead of the recent higher-resolution photos for road digitizing to ensure that the roads in our sample were at least $1 \mathrm{yr}$ old. Road 
Table 1. Study area locations; ecological sites; climate, vegetation, and disturbance characteristics; and road types investigated.

\begin{tabular}{|c|c|c|c|}
\hline & Wyoming & Utah & New Mexico \\
\hline Ecoregion $^{1}$ & Dry steppe & Semi-desert and desert & $\begin{array}{l}\text { Shrub and semi-shrub, semi-desert and } \\
\text { desert }\end{array}$ \\
\hline $\mathrm{MLRA}^{2}$ & Northern High Plains (58.2) & Colorado Plateau (35) & Chihuahaun Desert (42.2) \\
\hline Ecological site ${ }^{3}$ & Loamy (058BY122WY) & $\begin{array}{l}\text { Semi-desert shallow sandy loam } \\
\text { (035XY236UT) }\end{array}$ & Gravelly (R042XB010NM) \\
\hline Latitude, Iongitude & $-106^{\circ} 10.43^{\prime} \mathrm{E}, 44^{\circ} 2.48^{\prime} \mathrm{N}$ & $-109^{\circ} 47.88 \mathrm{E}, 38^{\circ} 34.09^{\prime} \mathrm{N}$ & $-106^{\circ} 40.90 \mathrm{E}, 32^{\circ} 11.19 \mathrm{~N}$ \\
\hline Precipitation (inches) ${ }^{4}$ & $10-14(25.4-35.6 \mathrm{~cm})$ & $10-20(25.4-50.8 \mathrm{~cm})$ & $8-10(20.3-25.4 \mathrm{~cm})$ \\
\hline $\begin{array}{l}\text { Historic climax plant } \\
\text { community }{ }^{4,5}\end{array}$ & $\begin{array}{l}\text { Cool season midstature grassland with } \\
\text { patches of big sagebrush (Artemisia } \\
\text { tridentata Nutt.) }\end{array}$ & $\begin{array}{l}\text { Mixed community co-dominated by trees } \\
\text { (Juniperus osteosperma Torr. and } \\
\text { Pinus edulis Engelm.) and shrubs } \\
\text { (Coleogyne ramosissima Torr.) with } \\
\text { strong biological soil crust development }\end{array}$ & $\begin{array}{l}\text { Mixed community co-dominated by } \\
\text { warm season grasses, shrubs, and } \\
\text { half-shrubs (primarily Larrea } \\
\text { tridentata DC. and Parthenium } \\
\text { incanum Kunth) }\end{array}$ \\
\hline Dominant disturbances & Natural gas wells and infrastructure & Recreation and natural gas exploration & $\begin{array}{l}\text { Recreational off-road vehicles and } \\
\text { pipeline infrastructure }\end{array}$ \\
\hline \multirow[t]{4}{*}{ Road types investigated ${ }^{6}$} & 1) Crown and Ditch & 1) Crown and Ditch & 1) Bladed \\
\hline & 2) Crown and Ditch with pipeline & 2) Bladed & 2) Bladed with pipeline \\
\hline & 3) Two Track & 3) Two Track & 3) Two Track \\
\hline & 4) Two Track with pipeline & 4) Intensive Use Areas & 4) Intensive Use Areas \\
\hline
\end{tabular}

${ }^{1}$ Bailey (1993).

${ }^{2}$ Major Land Resource Areas (US Department of Agriculture, Natural Resources Conservation Service [USDA-NRCS] 2002).

${ }^{3}$ USDA-NRCS (2003).

${ }^{4}$ From ecological site description.

${ }^{5}$ Approximately equivalent to reference condition for Interpreting Indicators of Rangeland Health evaluations.

${ }^{6}$ Table 2.

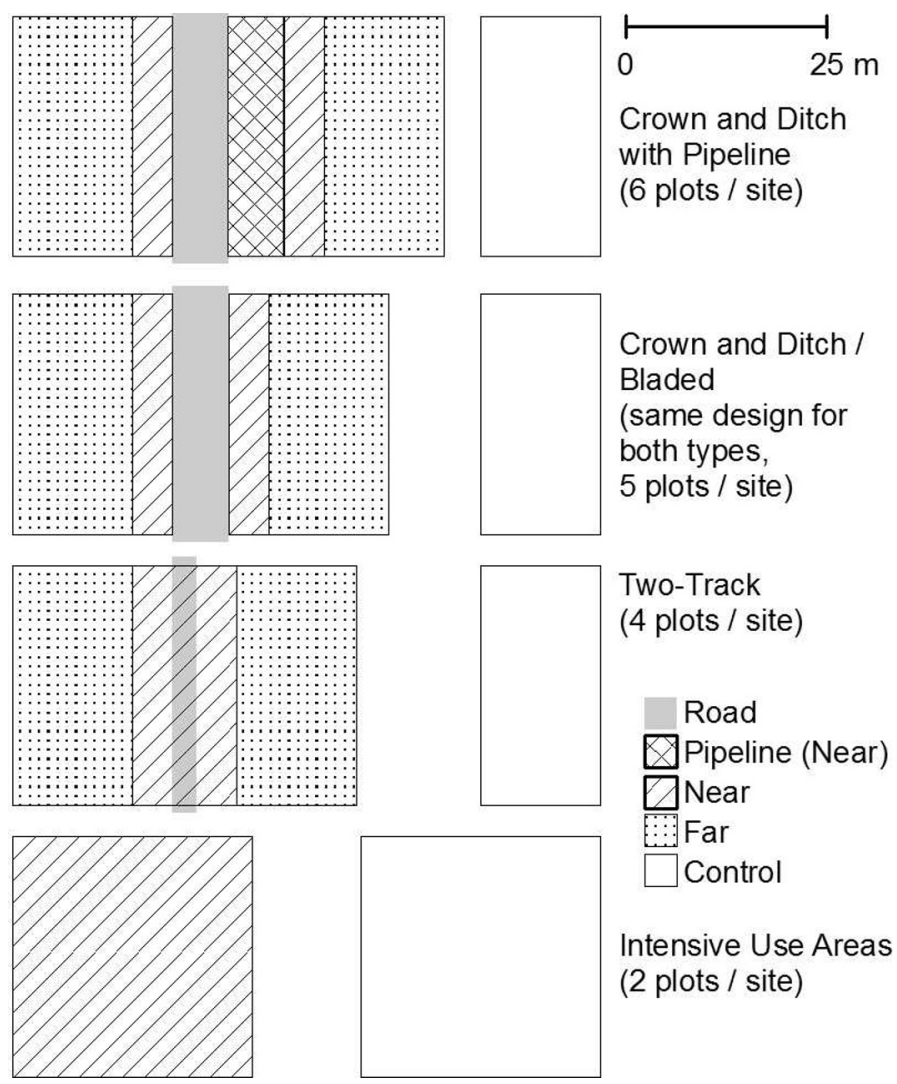

Figure 2. Layout of the disturbance (Near, $<5 \mathrm{~m}$; and Far, 5-20 m) and paired control plots ( $>40 \mathrm{~m}$ ) for the four road types studied. Roads (gray boxes) in Crown and Ditch and Bladed roads were not measured. Distance between control and disturbance plots not to scale. classification was validated by field visits to several segments of each road type. Road classes were chosen to represent typical construction designs and to differentiate road types that likely differ in the degree of impact to ecosystem functions based on the amount of disturbance and engineering involved (Brooks and Lair 2005). We overlaid randomly sorted segment sample populations on the 1:8000 photos in a geographic information system using $\operatorname{ArcMap}^{\circledR}$ version 9.1 (Environmental Systems Research Institute, Redlands, CA, USA). We visually classified segments into "high" or "low" indirect impacts by comparing patterns of vegetation, bare ground, and erosional features located within $20-30 \mathrm{~m}$ of the road to areas of similar topography and ecological site located at least $50 \mathrm{~m}$ from roads, trails, and pipelines (Table 3 ).

In the field, several plots were established at varying distances from the road at each site to test our ability to discern the extent of road impacts with IIRH (Figs. 2 and S1 [available at http://dx.doi.org/10.2111/REM-D-09-00176.sf1]). Road sites were divided into plots near $(<5 \mathrm{~m})$ and far from the linear feature $(5-20 \mathrm{~m})$. For two-track roads and two-track roads on top of pipelines, near plots were lumped with the disturbance (road or road plus pipeline) to create one continuous plot that included the disturbance plus $\sim 5 \mathrm{~m}$ on either side. For road types with more significant surface disturbance (Bladed and Crown and Ditch), the travel way was excluded from the IIRH evaluations and near plots on each side evaluated separately. For sites with pipelines along Bladed or Crown and Ditch roads, pipelines were evaluated separately.

A similar approach was used to create a stratified-random sample of sites with concentrated off-road and off-trail driving activity (Intensive Use Areas; Table 2). The 1:8000 photos were used because off-road vehicle tracks are often difficult to 
Table 2. Decision tree for classifying disturbances. This process was applied to stretches of road longer than the plots, generally on the order of several hundred meters. We limited our sample population to relatively narrow linear features that included a nonpaved road and were not planned parking areas, developed campgrounds, watering points for livestock, well pads, and very wide pipelines $(>\sim 20 \mathrm{~m}$; this occurred only in New Mexico).

1. Does the road have a discernable ${ }^{1}$ crown and ditch (raised in the center $>30 \mathrm{~cm}$ with a ditch on the side $>30 \mathrm{~cm}$ deep, relative to berm on side)? Yes, then Crown and Ditch. No, then:

2. Does the road have $<30 \%$ of total foliar cover (rooted within the road) of that in adjacent areas and have evidence of blading ${ }^{1}$ (berm $>\sim 30 \mathrm{~cm}$ )? Yes, then Bladed. No, then:

3. Is the segment within an area that has at least $75 \mathrm{~m}$ of vehicle tracks within a $30 \times 30 \mathrm{~m}$ square? Yes, then Intensive Use Area. No, then:

4. Two Track

${ }^{1}$ Evidence of past maintenance needed to be discernable in the field on the majority of the road stretch to be counted.

discern on 1:12 000 DOQQs. Intensive Use Areas had at least $75 \mathrm{~m}$ of tracks within a $30-\mathrm{m}$ square. This corresponds to approximately $25 \%$ cover of vehicle tracks with a standard sized sport utility vehicle (including areas between tires), a percent cover of tracks similar to that within near plots for Two-Track road type (Figs. 2 and S1 [available at http:// dx.doi.org/10.2111/REM-D-09-00176.sf1]). A sample population of Intensive Use Areas was identified using a hierarchical sampling approach. First, areas that appeared to have enough off-road vehicle activity were roughly delineated with large polygons. Then, a grid of points spaced at 10-m intervals was established within those polygons, and a layer of overlapping 30-m squares centered on each point created. Squares were evaluated in random order to determine if the amount of vehicle impacts within was sufficient to meet the minimum criteria for an Intensive Use Area plot (Table 2), and, if so, then qualitatively evaluated for impact (Table 3). Those plots that met the minimum qualifications for an Intensive Use Area plot but did not meet the qualifications for a high-impact Intensive Use Area plot were classified as low impact. Because roads and trails within Intensive Use Areas are not necessarily linear nor do they have an easily distinguished edge, we did not subdivide those sites by distance from disturbance and established only one $30 \times 30 \mathrm{~m}$ plot within the disturbed area (Fig. 2).

Paired control plots were established that were $>40 \mathrm{~m}$ from any vehicle-related disturbances for both road and Intensive Use Area plots to determine whether impacts detected in areas on or adjacent to roads were due to the disturbance of interest or other factors. Control plots matched disturbance plots as much as possible in all aspects, including soil series, soil surface texture, aspect, slope, slope shape, and dominant vegetation community (excluding changes in vegetation near the road). To the extent possible, control plots were not placed down slope of roads. For road sites, controls were a $15 \times 30 \mathrm{~m}$ rectangle (Fig. 2). For Intensive Use Area sites, controls were a $30 \times 30 \mathrm{~m}$ square (Fig. 2). Controls were oriented the same direction as road plots, except where slopes were $>3 \%$ and aspect differed between control and road plots, in which case slope orientation of control was matched with that of the disturbance plots.
Table 3. Qualitative imagery interpretation criteria for high ecological impact.

\begin{tabular}{lc}
\hline \multicolumn{1}{c}{ Site type } & \multicolumn{1}{c}{ Criteria for high impact } \\
\hline $\begin{array}{l}\text { Roads and roads with } \\
\text { pipelines }\end{array}$ & $\begin{array}{l}\text { Increase or decrease in vegetation or bare ground of } \\
>\sim 30 \% \text { or any observable increased frequency in } \\
\text { erosional features that extended greater than } 5 \mathrm{~m} \text { off } \\
\text { the road or pipeline }\end{array}$ \\
& $>\sim 60 \%$ ground not covered by litter, vegetation, or \\
Intensive Use Areas & biological soil crusts ${ }^{2}$ and/or $>60 \%$ covered with \\
& vehicle tracks ${ }^{2}$ (for four-wheeled vehicles, area \\
& between tires was included in track cover) \\
\hline
\end{tabular}

${ }^{1}$ Along 30-m road segment.

${ }^{2}$ Within $30 \times 30 \mathrm{~m}$ plot.

\section{Qualitative Assessments}

Qualitative assessments were conducted on each of 208 plots following the IIRH protocol, version 4 (Pellant et al. 2005). IIRH uses the ecological site concept (Herrick et al. 2006a) in combination with expert knowledge of soils and vegetation properties in a conceptual reference state. In the field, IIRH is conducted by an interdisciplinary team that evaluates the relative departure of 17 indicators of rangeland health (Table 4) against a description of the reference range of variation for each indicator using a five-category qualitative scale of departures (none-to-slight, slight-to-moderate, moderate, moderate-to-extreme, or extreme-to-total). Once all indicators have been evaluated, three attributes of rangeland health (Soil and Site Stability, Hydrologic Function, and Biotic Integrity; Pellant et al. 2005) are evaluated by synthesizing the five-category scale of departure ratings for the relevant indicators for each attribute (Table 4). The existing reference sheets for the ecological sites required updating. For each state, we updated reference sheets by reviewing available literature and unpublished data, and consulting with a group of local experts. Ecological site-specific reference matrices were developed based on these reference sheets (Pellant et al. 2005).

Field work was conducted in September 2007 in Wyoming, November and December 2007 in New Mexico, and March 2008 in Utah. An interdisciplinary three-person team (range scientist, botanist, and soil scientist), each of whom had received at least two 1-wk formal IIRH trainings, conducted independent evaluations, which were then followed by a consensus evaluation. Bare ground and litter cover, which is necessary for IIRH, was estimated with 100 points collected by the step-point technique (Evans and Love 1957). Soil stability values (collected as part of the quantitative measures; see next section) and steppoint litter and bare ground cover were shared among observers for individual and consensus evaluations.

\section{Quantitative Measures}

Quantitative measures were completed within 1-14 d after qualitative measures. Five transects were strung across plots, perpendicular to roads and pipelines (if present) and oriented parallel to one square side for Intensive Use Area sites (Fig. S1 [available at http://dx.doi.org/10.2111/REM-D-09-00176.sf1]). Transects in the control were oriented in the same direction as in the disturbance plots. A line-point intercept (LPI) with a point spacing of $30 \mathrm{~cm}$ was used to collect vegetation cover and 
Table 4. Interpreting Indicators of Rangeland Health indicator numbers, description, attributes with which indicators are associated (dots), and Friedman's test results comparing the distribution of the indicator departure rating in the Near, Far, and Control plots (Fig. 2) in each study area. Adapted from Pellant et al. (2005).

\begin{tabular}{|c|c|c|c|c|c|c|c|}
\hline \multicolumn{2}{|c|}{ Qualitative indicators } & \multicolumn{3}{|c|}{ Attribute $^{1}$} & \multicolumn{3}{|c|}{ Friedman's test ${ }^{2}$} \\
\hline No. & Description & SSS & HF & $\mathrm{Bl}$ & WY & UT & NM \\
\hline 1 & Number and extent of rills & $\bullet$ & $\bullet$ & & $\star \star *$ & & \\
\hline 2 & Presence of water flow patterns & $\bullet$ & $\bullet$ & & ** & & \\
\hline 3 & Number and height of erosional pedestals or terracettes & $\bullet$ & $\bullet$ & & & & * \\
\hline 4 & Bare ground & $\bullet$ & $\bullet$ & & ** & ** & ** \\
\hline 5 & Number of gullies and erosion associated with gullies & $\bullet$ & $\bullet$ & & & & \\
\hline 6 & Extent of wind scoured, blowouts, and/or depositional areas & $\bullet$ & & & & ** & \\
\hline 7 & Amount of litter movement & $\bullet$ & & & ** & $\star \star$ & \\
\hline 8 & Soil surface (top few $\mathrm{mm}$ ) resistance to erosion & $\bullet$ & $\bullet$ & $\bullet$ & $\star *$ & $* *$ & \\
\hline 9 & Soil surface structure and soil organic matter content & $\bullet$ & $\bullet$ & $\bullet$ & $* *$ & $\star *$ & ** \\
\hline 10 & $\begin{array}{l}\text { Effect of plant community composition and spatial distribution on infiltration } \\
\text { and runoff }\end{array}$ & & $\bullet$ & & $\star *$ & ** & \\
\hline 11 & Presence and thickness of compaction layer & $\bullet$ & $\bullet$ & $\bullet$ & ** & ** & * \\
\hline 12 & Functional/structural groups & & & $\bullet$ & & $\star \star$ & \\
\hline 13 & Amount of plant mortality and decadence & & & $\bullet$ & & & \\
\hline 14 & Average percent litter cover & & $\bullet$ & $\bullet$ & & & * \\
\hline 15 & Expected annual production & & & $\bullet$ & ** & & \\
\hline 16 & Potential invasive (including noxious) species (native and non-native) & & & $\bullet$ & & & \\
\hline 17 & Perennial plant reproductive capability & & & $\bullet$ & & & \\
\hline
\end{tabular}

${ }^{1}$ SSS indicates Soil and Site Stability; HF, Hydrologic Function; BI, Biotic Integrity.

${ }^{2}$ Nonparametric ANOVA testing if the indicator departure rating distributions differed between Near, Far, or Control plots (Fig. 2) in Wyoming, Utah, and New Mexico. * indicates Friedman's significant at the 0.05 probability level; ** indicates Friedman's significant at the 0.01 probability level.

composition, basal cover, and ground cover data (Herrick et al. 2005). The 30-cm spacing interval was chosen to ensure that at least 80 points were collected in the narrowest plots $(5 \mathrm{~m})$. In addition to vegetation and soil surface cover data collected with LPI, we also recorded vegetation height every $150 \mathrm{~cm}$ and recorded dead or decadent plants by recording all hits where the whole plant or plant part intersected was either dead or decadent. To evaluate the susceptibility of sites to wind erosion and weed invasion, size of gaps between perennial plant canopies were measured along the same transects (Herrick et al. 2005).

Soil aggregate stability samples were collected from each plot and analyzed using a soil stability field kit (Herrick et al. 2001, 2005). This method has been shown to be highly sensitive to changes in soil surface structure in New Mexico (Bird et al. 2007), Utah (Chaudhary et al. 2009), and Wyoming (Herrick et al. 2006b). Eighteen samples were collected from each plot in Utah and New Mexico. Only nine samples were collected from each plot in Wyoming because of time and staff limitations. Approximately half of the samples were collected from underneath perennial plant canopies and half outside of these canopies using a stratified (by canopy) random sampling design. Plot averages were generated with weighted strata averages using transect cover data.

To provide a quantitative estimate of rill and gully formation in plots independent of IIRH, depth and width of rill and gully features were measured along continuous transects within each plot by a person not involved in IIRH assessments. For road plots, rill and gully transects were walked approximately up the center of the road and pipeline (if present) and approximately $2.5 \mathrm{~m}$ and $12.5 \mathrm{~m}$ out from the road edge and parallel to the road on either side. Additionally, two evenly spaced transects were walked across all plots perpendicular to roads. For Intensive Use Area sites, two sets of two intersecting transects were walked. Transects were evenly spaced, parallel to plot edges, and measured as above.

\section{Statistical Analysis}

To assess the sensitivity of IIRH attributes and indicators to impacts caused by roads (objective 1) in each study area, we used a nonparametric randomized block analysis of variance (ANOVA, Friedman's test blocking on site, PROC FREQ; SAS 2001) to test the null hypothesis that the distribution of departure classes in Near and Far plots was not different than in the Controls. At the attribute level, this was done separately for Near and Far for each study area, and for each road type in each study area. Although it is generally not recommended to emphasize individual IIRH indicators (Pellant et al. 2005), we were interested in determining the relative sensitivity of different IIRH indicators to linear disturbances. Therefore we also conducted the nonparametric randomized block ANOVA as above at the indicator level in each study area but tested only the hypothesis that at least one of the set of plots (Near, Far, or Control) was from a different distribution, and we did not conduct the analysis for the different road types separately.

To test if the level of agreement among observers conducting IIRH evaluations along roads or in vehicle-disturbed areas was significantly less than in nondisturbed areas and thus possibly limit IIRH applicability in such situations (objective 2), we calculated the range in attribute ratings for the three observers in each plot $(0=$ all observers had same departure rating, $1=$ observers differed by one departure class, $2=$ observers differed by two departure classes, and $3=$ observers differed by three departure classes). The frequency of attribute departure 
rating ranges $(0,1,2$, and 3$)$ was then calculated for each group of plots (Near, Far, and Control) for each IIRH attribute. A chisquare test of homogeneity was used to test if the observers experienced a similar amount of agreement in the three groups of plots (Near, Far, and Control) for each IIRH attribute. Although IIRH ratings (either at the indicator or attribute level) are not necessarily evenly spaced in a conceptual ecological process space (i.e., the distance between none-to-slight and slight-to-moderate is not necessarily the same as the distance between moderate-to-extreme and extreme-to-total), this approach does allow us to compare levels of agreement among observers without treating ratings as a continuous variable.

To assess the extent to which trends in IIRH attribute departure ratings were correlated with quantitative indicators (objective 3), we compared the ratings with both individual quantitative indicators and attribute-specific quantitative indices. LPI, canopy gap, soil stability, and rill and gully quantitative data were summarized for each plot to create three sets of quantitative indicators corresponding to the three IIRH qualitative attributes (Pyke et al. 2002; Pellant et al. 2005). These three sets of indicators were then used to generate a quantitative indicator index for each attribute based on the axis score of an ordination of the values of the quantitative variables on all plots. Nonmetric Multidimensional Scaling with Sorensen distance measure and limiting the final dimensionality to one axis (PCORD; McCune and Mefford 2006) was used to create the quantitative indicator index. Spearman's rank correlations were then used to compare both the individual quantitative indicators and the quantitative indicator indices with the three attributes (PROC CORR; SAS Institute 2001).

\section{RESULTS}

\section{Sensitivity of IIRH to Road Impacts}

Attribute Level. Significant differences in qualitative attribute rating distributions $(P<0.05)$ were detected among the three distance classes (Near, $<5 \mathrm{~m}$; Far, 5-10 m; and Control, $>40 \mathrm{~m}$ ) with greater plot attribute departure from reference condition near disturbances (Fig. 3, open bars) across most attributes and each study area. In all three study areas, the differences between Control and disturbed plots (Near and Far) attribute rating departures were generally greater in Soil and Site Stability and Hydrologic Function than in Biotic Integrity (Fig. 3). There was no significant difference in Biotic Integrity distributions among distance classes in New Mexico, and significant differences detected in Wyoming and Utah were primarily driven by differences in the Near but not the Far plots. Results indicate that the stratified random plot selection process used was successful in obtaining a wide range in IIRH attribute ratings among road and control plots in all states and attributes except for Hydrologic Function and Biotic Integrity in New Mexico, where $>85 \%$ of plots were within one departure class (either slight-to-moderate or moderate; Fig. 3).

Examination of IIRH assessment results within road types indicates that changes in the rangeland health of the sites studied (relative to Controls, $>40 \mathrm{~m}$ from roads) appears to be limited to $<5 \mathrm{~m}$ off the road (Near plots) in most instances. For the ecological sites investigated, detectable impacts to rangeland health (with differences in departure distributions significantly different, $\alpha=0.05$ ) extend farther than $5 \mathrm{~m}$ (to negatively impact Far plots) only in Hydrologic Function for Two Track with Pipelines in Wyoming ( $P=0.046$; see Fig. S2, available at http:// dx.doi.org/10.2111/REM-D-09-00176.sf2), Soil and Site stability for Crown and Ditch in Utah $(P=0.041$; see Fig. S3, available at http://dx.doi.org/10.2111/REM-D-09-00176.sf3), and Hydrologic Function for Bladed in New Mexico $(P=0.041$; see Fig. S4, available at http://dx.doi.org/10.2111/ REM-D-09-00176.sf4). Crown and Ditch (with or without pipelines) types investigated in Wyoming and Utah consistently had a significant impact on all attributes. For Bladed roads, no differences in attribute departure rating distributions were detected among distance classes (Near, Far, and Control) in Utah, and differences were detected in New Mexico only in Hydrologic Function $(P=0.041$ for both Near and Far). Similarly, there were very few differences detected in Two Tracks (without pipelines) except for in Hydrologic Function of Near plots in Utah $(P=0.046)$. Differences in all attributes of IIRH were detected for the Utah Intensive Use Areas, but no differences were detected in New Mexico.

Indicator Level. Analysis of the 17 IIRH indicators found that only 3 of the 17 were significantly different among plots at different distances from roads (Near, $<5 \mathrm{~m}$; Far, 5-20 m; and Control, $>40 \mathrm{~m}$ ) in all three study locations (Table 4): the amount and distribution of bare ground (indicator 4), soil surface loss or degradation (indicator 9), and presence and thickness of a compaction layer (indicator 11). An additional three indicators were significantly different in Wyoming and Utah but not New Mexico: amount of litter movement (indicator 7), soil surface resistance to erosion (indicator 8), and the effect of plant community composition and spatial distribution on infiltration and runoff (indicator 10). There were far fewer indicators that showed significant differences among plots in New Mexico (total of five) than in Utah or Wyoming (total of eight to nine).

\section{Variability Among IIRH Observers}

Analysis of the distribution of the range in attribute departure ratings (Fig. 4) indicates that the amount of agreement among observers in the three distance classes (Near, $<5 \mathrm{~m}$; Far, 5$20 \mathrm{~m}$; and Control, $>40 \mathrm{~m}$ ) was only significantly different $(P<0.05)$ for Soil and Site Stability in Wyoming. This difference detected in Wyoming was partially due to the very high level of agreement in Soil and Site Stability in the Wyoming Controls (same attribute rating among three observers at $75 \%$ of the control plots). Otherwise, observers appeared to agree to a similar extent among the groups of plots.

\section{Correlations of Quantitative and IIRH Attributes}

Individual Quantitative Indicators. The strength of correlations between quantitative and qualitative indicators provides insight into which quantitative measures are important for capturing the variability present along roads (Tables 5-7). The amount of bare ground and the connectivity of the bare ground (bare ground in gaps $>100 \mathrm{~cm}$ ) were strongly correlated with both Soil and Site Stability and Hydrologic Function in all three study areas. Other quantitative measures, such as the amount of rill and gully 


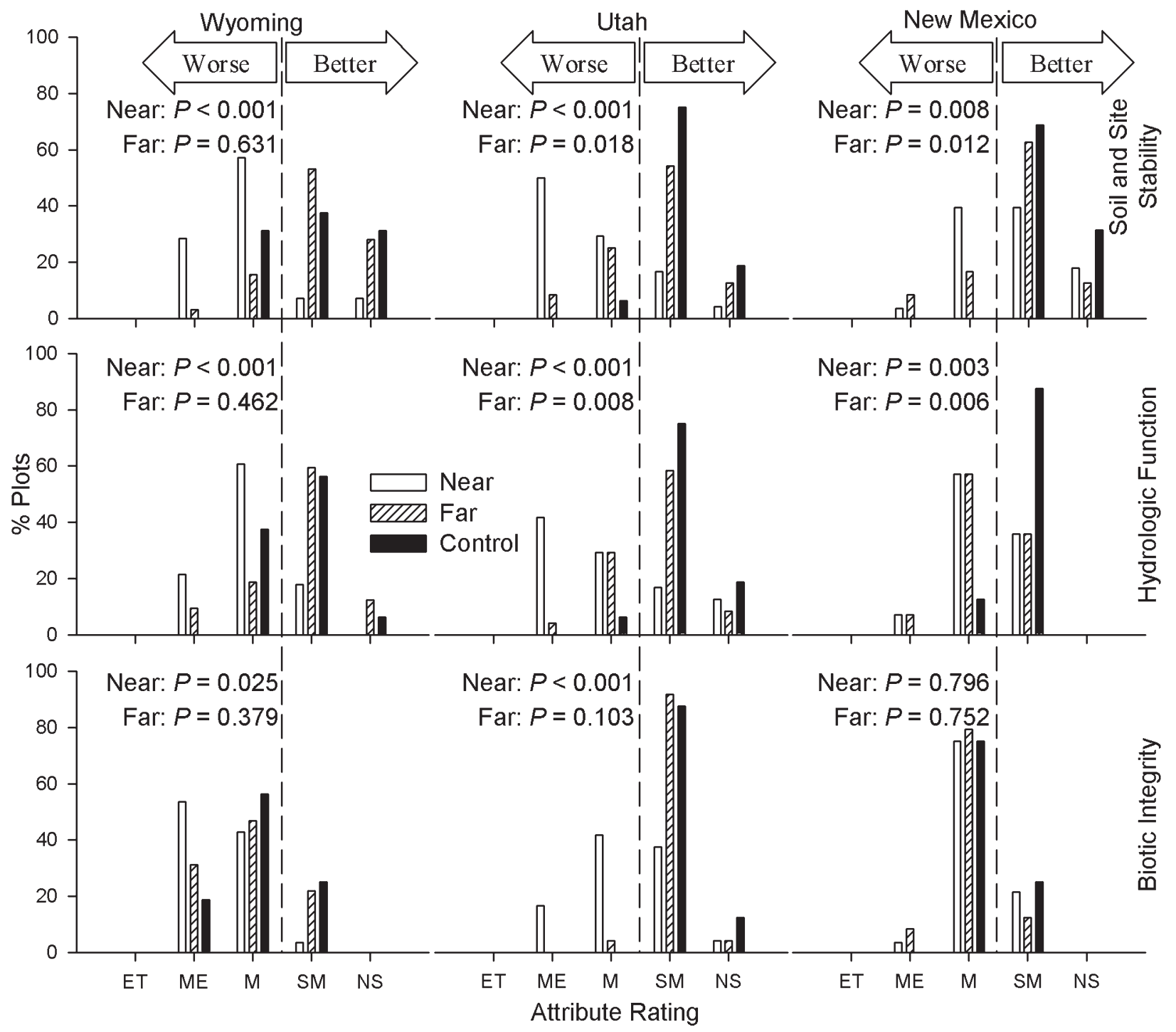

Figure 3. Interpreting Indicators of Rangeland Health (IIRH) attribute ratings for plots at different distances from the disturbance in each study area (Wyoming, Utah, and New Mexico) and for each IIRH attribute (Soil and Site Stability, Hydrologic Function, and Biotic Integrity). "Better" and "Worse" arrows and vertical dashed line between M and SM are provided to help interpret which distance classes are predominately closer to reference condition (NS, none-to-slight; or SM, slight-to-moderate) versus farther from reference condition (M, moderate; ME, moderate-to-extreme; or ET, extreme-to-total). Near plots include areas $<5 \mathrm{~m}$ from disturbances (including areas on two-track roads, pipelines, and Intensive Use Areas). Far plots are areas are between $5 \mathrm{~m}$ and $20 \mathrm{~m}$ of the disturbance. Controls are at least $40 \mathrm{~m}$ away from the disturbance (Fig. 2). $P$ values are from Friedman's tests comparing the distribution of the Near vs. Control ("Near") and Far vs. Control ("Far") class attribute departure ratings.

development, were strongly correlated with Soil and Site Stability and Hydrologic Function in Wyoming and New Mexico but not in Utah. Conversely, plot average as well as protected and unprotected strata soil aggregate stability were highly correlated with all three attributes in Utah, but correlations were not as strong or consistent in Wyoming or New Mexico. Cover of all plant canopies, cover of plant species that were described in the reference sheet as being important for water capture, and litter cover were all correlated with Hydrologic Function in Wyoming. In Utah, litter and biological crust cover were correlated with Hydrologic Function but not plant cover measures. Similarly, plant community composition measures (functional/structural groups and cover of invasives) were highly correlated with Biotic Integrity in Wyoming but not in Utah or New Mexico.
Quantitative Indicator Indices. Trends in the multivariate quantitative indices followed the same trends as the qualitative attributes in most instances (Table 8). Except for Biotic Integrity in Utah and New Mexico, all correlations were significant $(P<0.05)$.

\section{DISCUSSION}

Results of this study indicate that IIRH is both sensitive to impacts and correlated to quantitative measures across many types of road-related disturbances and a broad range of ecosystems, although the severity of impacts detected varied. IIRH attribute ratings indicate that hydrologic function and soil and site stability are the primary ecosystem processes negatively 

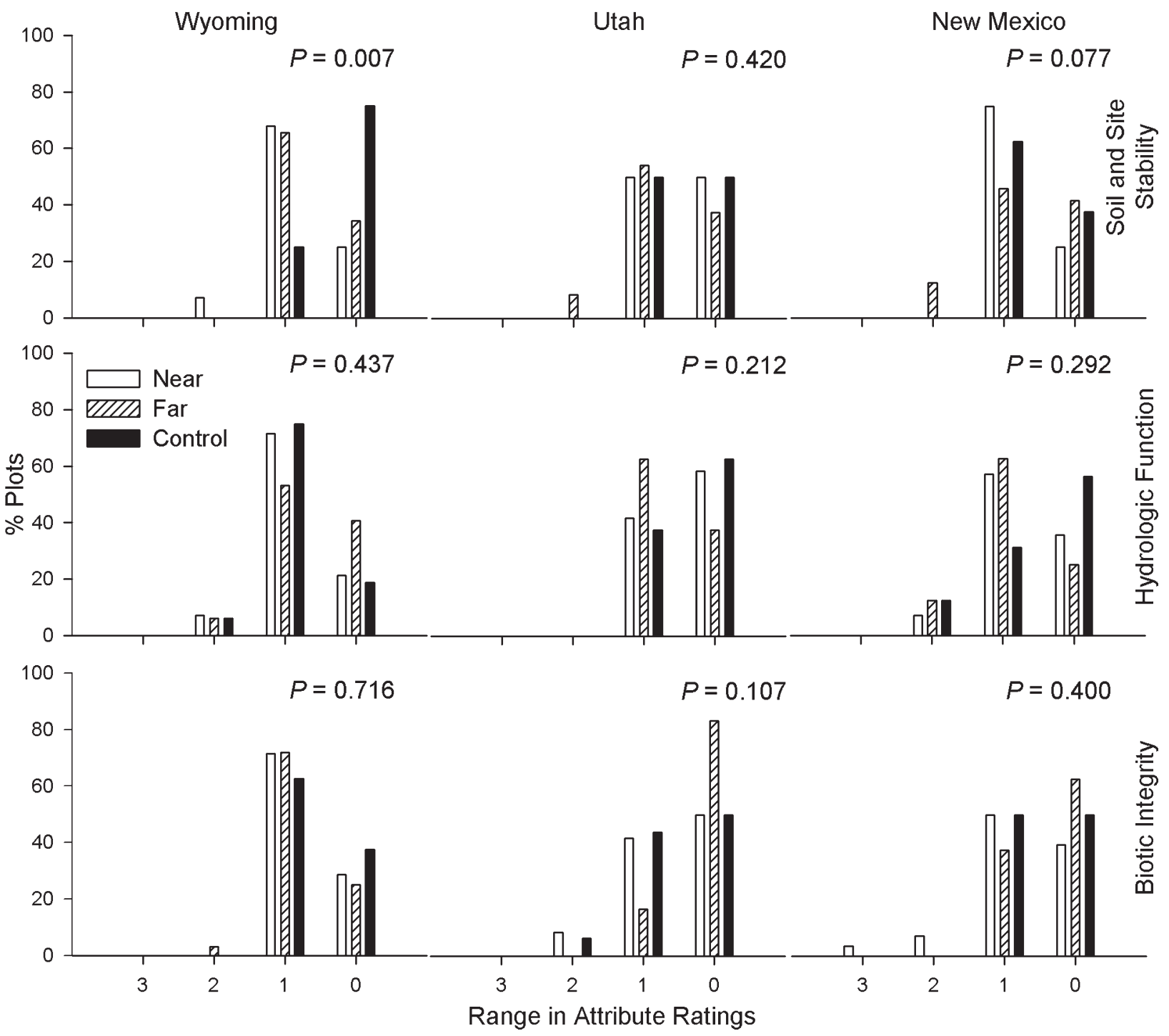

Figure 4. Range in Interpreting Indicators of Rangeland Health (IIRH) attribute ratings among the three observers $(0=$ all observers had same departure rating, 3 = observers differed by three departure classes) within plots and frequency of occurrence in each distance class in each study area (Wyoming, Utah, and New Mexico) and for each IIRH attribute (Soil and Site Stability, Hydrologic Function, and Biotic Integrity). Near plots include areas $<5 \mathrm{~m}$ from disturbances (including areas on two-track roads, pipelines, and Intensive Use Areas). Far plots are areas are between $5 \mathrm{~m}$ and $20 \mathrm{~m}$ of the disturbances. Controls are at least $40 \mathrm{~m}$ away from the disturbance. $P$ values indicate probability that the distribution of agreement among observers is the same among distance classes (within attribute and study area).

impacted by road, trail, and pipeline development across all three ecological sites studied. Analysis of coupled qualitativequantitative measures indicates that commonly applied quantitative techniques capture some of the same information on ecosystem processes as captured by IIRH. For effective monitoring of road-related disturbance, however, other quantitative methods are needed that are sensitive to inter-rill erosion and soil degradation.

\section{Sensitivity of IIRH Attributes to Disturbances}

The differences in the range of IIRH attribute ratings among study areas were likely due to a combination of factors, including the severity of the disturbance associated with the linear features investigated, historical disturbance regimes, resilience of the chosen ecological sites to road disturbances, resultant ecological states, and power of the qualitative methods to detect change. Many of the nonroad, control plots studied in Wyoming were in a degraded state relative to their potential, particularly the biotic components (Fig. 3). Although the area evolved with periodic grazing by native ungulates (antelope and bison; Mack and Thompson 1982), there have been periods of overgrazing by domesticated livestock (sheep and cattle) in historical times (Fleischner 1994). According to the ecological site description, the historical climax plant community is a cool-season perennial grassland with some sagebrush (Artemisia tridentata Nutt.). However, almost all Wyoming Control sites studied were either heavily invaded by cheatgrass (Bromus tectorum L.), dominated by sagebrush with few perennial grasses, or both, resulting in frequent departures from the reference condition (moderate and some moderate-toextreme attribute ratings; Fig. 3). Disturbances caused by road and pipeline developments impacted the ecological function of 
Table 5. Relationship between quantitative measures and Interpreting Indicators of Rangeland Health Soil and Site Stability attribute ratings in the three study areas (based on Spearman's Rank correlation). ${ }^{1}$

\begin{tabular}{|c|c|c|c|c|c|c|c|}
\hline \multirow[b]{2}{*}{ Quantitative measure } & \multirow[b]{2}{*}{ Pred. $^{2}$} & \multicolumn{2}{|c|}{ Wyoming $(n=76)$} & \multicolumn{2}{|c|}{ Utah $(n=64)$} & \multicolumn{2}{|c|}{ New Mexico $(n=68)$} \\
\hline & & $\rho$ & $P$ & $\rho$ & $P$ & $\rho$ & $P$ \\
\hline Rills and gullies ${ }^{3}$ & + & 0.31 & $0.007^{\star *}$ & -0.07 & 0.570 & 0.41 & 0.000 ** \\
\hline Basal cover & - & -0.26 & $0.022^{*}$ & -0.19 & 0.12 & -0.11 & 0.367 \\
\hline Gaps $>100 \mathrm{~cm}$ & + & 0.16 & 0.158 & 0.22 & 0.08 & 0.13 & 0.273 \\
\hline Bare ground & + & 0.73 & $0.000 * *$ & 0.70 & $0.00^{* *}$ & 0.33 & $0.006^{\star *}$ \\
\hline Bare ground in gaps $>100 \mathrm{~cm}$ & + & 0.68 & $0.000^{* *}$ & 0.63 & $0.00^{* *}$ & 0.34 & $0.004^{* *}$ \\
\hline Interspace litter & $+1-$ & -0.68 & $0.000^{* *}$ & -0.39 & $0.00^{* *}$ & -0.05 & 0.713 \\
\hline Ratio canopy/interspace litter & - & -0.47 & $0.000 * *$ & 0.00 & 0.98 & -0.27 & $0.024^{*}$ \\
\hline Average soil stability & - & -0.61 & $0.000^{* *}$ & -0.83 & $0.00 * *$ & -0.09 & 0.462 \\
\hline Protected soil stability & - & -0.23 & $0.043^{*}$ & -0.35 & $0.00^{* *}$ & 0.02 & 0.864 \\
\hline Unprotected soil stability & - & -0.67 & $0.000^{* *}$ & -0.83 & $0.00^{* *}$ & 0.07 & 0.576 \\
\hline
\end{tabular}

$1 *$ indicates correlation significant at the 0.05 probability level; ${ }^{* *}$ indicates correlation significant at the 0.01 probability level.

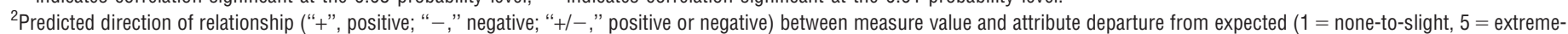
to-total).

${ }^{3}$ Natural $\log$ of $\Sigma(D \times W)$ rills and gullies, where $D=$ depth and $W=$ width of rill or gully feature.

these sites such that differences were detected by IIRH (Near plots; Fig. 3). In addition to the three IIRH indicators that showed significant variability among distance classes in all study locations (bare ground, soil surface loss and degradation, and presence and thickness of a compaction layer; Table 4), significant differences in several other IIRH indicators suggests that changes in overland flow and water retention are important on this fine-textured ecological site (number of rills, presence of waterflow patterns, and amount of litter movement).

In the Shallow Sandy Loam ecological site investigated in Utah, the Controls were in a slightly degraded state (very few Controls with attribute departures worse than slight-to-moderate; Fig. 3). Road and trail development on these shallow sandy soils with strong biological crust development appears to impact ecological processes such that impacts are readily detected by IIRH. Impacts to Biotic Integrity appear to be limited to areas directly impacted or immediately adjacent to roads (Near) but impacts to Soil and Site Stability and Hydrologic Function included areas $>5 \mathrm{~m}$ from the roads (Near and Far; Fig. 3). The IIRH indicators related to overland flow that were important in Wyoming (number and extent of rills and presence of water flow patterns) were not as important in Utah but effects of wind erosion and deposition were important (Table 4). This difference is likely related to the contrasting soil textures of the two sites investigated. Changes to site ecohydrologic properties are likely less important in the sandy site investigated in Utah than the finer textured (loamy) site investigated in Wyoming. Conversely, the sandy site in Utah would likely be much more sensitive to changes in susceptibility to wind erosion (such as breaking up of biological soil crusts and loss of vegetative cover) than the Loamy site in Wyoming.

The Gravelly ecological site studied in New Mexico was primarily in a shrubland state, dominated by creosote bush

Table 6. Relationship between quantitative measures and Interpreting Indicators of Rangeland Health Hydrologic Function attribute ratings at the three pilot areas (based on Spearman's Rank correlation). ${ }^{1}$

\begin{tabular}{|c|c|c|c|c|c|c|c|}
\hline \multirow[b]{2}{*}{ Quantitative measure } & \multirow[b]{2}{*}{ Pred. $^{2}$} & \multicolumn{2}{|c|}{ Wyoming $(n=76)$} & \multicolumn{2}{|c|}{ Utah $(n=64)$} & \multicolumn{2}{|c|}{ New Mexico $(n=68)$} \\
\hline & & $\rho$ & $P$ & $\rho$ & $P$ & $\rho$ & $P$ \\
\hline Rills and gullies ${ }^{3}$ & + & 0.37 & $0.001^{* *}$ & -0.05 & 0.716 & 0.55 & $0.000^{* *}$ \\
\hline Basal cover & - & -0.19 & 0.097 & -0.18 & 0.161 & -0.32 & $0.009^{\star *}$ \\
\hline Gaps $>100 \mathrm{~cm}$ & + & 0.26 & $0.025^{\star}$ & 0.30 & $0.016^{\star}$ & 0.16 & 0.195 \\
\hline Bare ground & + & 0.77 & $0.000^{* *}$ & 0.60 & $0.000^{* *}$ & 0.28 & $0.019^{\star}$ \\
\hline Bare ground in gaps $>100 \mathrm{~cm}$ & + & 0.73 & $0.000^{* *}$ & 0.58 & $0.000^{* *}$ & 0.32 & $0.009^{\star *}$ \\
\hline Average soil stability & - & -0.54 & $0.000^{* *}$ & -0.77 & $0.000 * *$ & -0.26 & $0.031^{*}$ \\
\hline Protected soil stability & - & -0.21 & 0.067 & -0.48 & $0.000^{* *}$ & -0.19 & 0.128 \\
\hline Unprotected soil stability & - & -0.58 & $0.000^{* *}$ & -0.75 & $0.000^{* *}$ & -0.10 & 0.398 \\
\hline All points with biological soil crust & - & NA & NA & -0.76 & $0.000^{* *}$ & NA & NA \\
\hline Canopy cover & - & -0.32 & $0.004^{* *}$ & -0.14 & 0.287 & -0.14 & 0.240 \\
\hline High infiltration/capture species ${ }^{4}$ & - & -0.73 & $0.000^{* *}$ & 0.23 & 0.064 & -0.23 & 0.065 \\
\hline Litter cover & $+/-$ & -0.75 & $0.000^{* *}$ & -0.31 & $0.013^{*}$ & -0.12 & 0.313 \\
\hline
\end{tabular}

${ }^{1} \mathrm{NA}$ indicates measurement not applicable. ${ }^{*}$ indicates correlation significant at the 0.05 probability level; ${ }^{* *}$ indicates correlation significant at the 0.01 probability level.

2Predicted direction of relationship ("+," positive; "-," negative; "+- -," positive or negative) between measure value and attribute departure from expected ( $1=$ none-to-slight, $5=$ extremeto-total).

${ }^{3}$ Natural $\log$ of $\Sigma(\mathrm{D} \times \mathrm{W})$ rills and gullies, where $\mathrm{D}=$ depth and $\mathrm{W}=$ width of rill or gully feature.

${ }^{4}$ Cover of plant species that should improve site water capture and infiltration as described in the reference sheet. 
Table 7. Relationship between quantitative measures and Interpreting Indicators of Rangeland Health Biotic Integrity attribute ratings at the three study areas (based on Spearman's Rank correlation). ${ }^{1}$

\begin{tabular}{|c|c|c|c|c|c|c|c|}
\hline \multirow[b]{2}{*}{ Quantitative measure } & \multirow[b]{2}{*}{ Pred. $^{2}$} & \multicolumn{2}{|c|}{ Wyoming $(n=76)$} & \multicolumn{2}{|c|}{ Utah $(n=64)$} & \multicolumn{2}{|c|}{ New Mexico $(n=68)$} \\
\hline & & $\rho$ & $P$ & $\rho$ & $P$ & $\rho$ & $P$ \\
\hline Average soil stability & - & -0.15 & 0.199 & -0.75 & $0.000^{* *}$ & -0.22 & 0.073 \\
\hline Protected soil stability & - & -0.18 & 0.117 & -0.51 & $0.000^{* *}$ & -0.06 & 0.636 \\
\hline Unprotected soil stability & - & -0.06 & 0.613 & -0.72 & $0.000^{* *}$ & -0.17 & 0.174 \\
\hline No. dominants ${ }^{3}$ & - & -0.11 & 0.359 & -0.32 & $0.010^{\star *}$ & -0.21 & 0.080 \\
\hline$\%$ dominant $^{4}$ & - & -0.46 & $0.000^{* *}$ & -0.21 & 0.090 & -0.02 & 0.841 \\
\hline$\%$ subdominant $^{4}$ & - & -0.32 & $0.005^{\star *}$ & 0.02 & 0.891 & -0.03 & 0.820 \\
\hline$\%$ other $^{4}$ & $+1-$ & 0.67 & $0.000^{* *}$ & -0.20 & 0.113 & 0.08 & 0.535 \\
\hline Biological soil crust cover ${ }^{5}$ & - & - & - & -0.77 & $0.000^{* *}$ & NA & NA \\
\hline Ratio dead/live & + & -0.02 & 0.886 & -0.18 & 0.151 & -0.03 & 0.820 \\
\hline Litter cover & $+1-$ & 0.16 & 0.177 & -0.38 & $0.002^{* *}$ & -0.17 & 0.170 \\
\hline Live vascular hits & - & -0.14 & 0.214 & -0.29 & $0.020^{*}$ & -0.22 & 0.073 \\
\hline Vegetation height & - & -0.13 & 0.247 & -0.11 & 0.383 & 0.11 & 0.378 \\
\hline Live invasive cover & + & 0.49 & $0.000^{* *}$ & NA & NA & 0.19 & 0.116 \\
\hline
\end{tabular}

${ }^{1} \mathrm{NA}$ indicates measurement not applicable. ${ }^{*}$ indicates correlation significant at the 0.05 probability level; ${ }^{* *}$ indicates correlation significant at the 0.01 probability level.

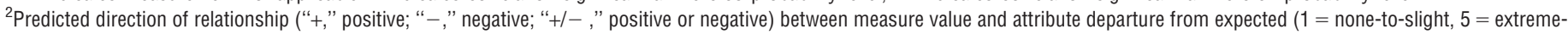
to-total).

${ }^{3}$ Number of species in the Dominant Functional Structural (F/S) group.

${ }^{4}$ Percent composition of F/S group (live hits only).

${ }^{5}$ Percentage of available soil surface habitat, excluding exposed bedrock and areas covered by rocks, litter, and plant basal.

(Larrea tridentata DC). According to the Ecological Site Description (USDA-NRCS 2003), this is a degraded ecological state due to a variety of factors including historical grazing, fire suppression, and drought (many Control plots with moderate attribute ratings; Fig. 3). Although Biotic Integrity attribute ratings of disturbed plots (Near and Far) were not significantly different than the Controls (Fig. 3), the disturbances investigated in New Mexico did alter the ecological processes of these sites such that significant differences were detected in Soil and Site Stability and Hydrologic Function. The indicators that were responsible for the difference in attribute ratings among plots included severity and frequency of formation of pedestals and terracettes around plants and rocks (indicator 3), amount and distribution of bare ground (indicator 4), and loss or degradation of soil surface (indicator 9; Table 4). This indicates that most of the impacts associated with roads in the Gravelly ecological site in New Mexico are related to soil degradation and inter-rill erosion. None of the indicators relating to plant community cover and composition appeared to be important for detecting road impacts in this ecological site.

\section{Which Indicators to Use for Monitoring of Linear Features?}

Although IIRH is very effective for assessments, the greater precision provided by quantitative indicators is almost always required for rangeland monitoring, including monitoring impacts due to the presence and use of linear features. For the ecological sites investigated, changes to hydrologic function and soil and site stability appear to be more important than changes to biotic integrity, indicating that a successful monitoring plan should include quantitative indicators that can capture important changes to hydrology and soils. Paired IIRH assessments of areas near roads and trails and areas far from vehicle disturbances can help guide selection of quantitative indicators for monitoring and will also likely help provide context for changes observed in monitoring programs. Results from this study indicate line-point intercept and canopy gap measures should be included. These data can be summarized to capture information related to six of the 13 indicators (Pellant et al. 2005 , p. 112) that were significantly different among road and nonroad plots in at least one study location (Table 4). Additionally, soil aggregate stability measures (Herrick et al. 2001) and (though not included in this study because of the presence of buried pipelines) measures of compaction (Herrick and Jones 2002) should also be included to capture information related to two additional IIRH indicators that appear to be important for detecting road impacts (Table 4).

Notably absent from the list in Pellant et al. (2005, p. 112) and Pyke et al. (2002) are any standard monitoring protocols

Table 8. Relationship between ordination of quantitative indicators and Interpreting Indicators of Rangeland Health attribute departure ratings at the three study areas (based on Spearman's Rank correlation). ${ }^{1}$

\begin{tabular}{|c|c|c|c|c|c|c|}
\hline \multirow[b]{2}{*}{ Attribute } & \multicolumn{2}{|c|}{ Wyoming $(n=76)$} & \multicolumn{2}{|c|}{ Utah $(n=64)$} & \multicolumn{2}{|c|}{ New Mexico $(n=68)$} \\
\hline & $\rho$ & $P$ & $\rho$ & $P$ & $\rho$ & $P$ \\
\hline Soil and Site Stability & -0.73 & $<0.001^{\star *}$ & 0.70 & $<0.001^{* *}$ & 0.32 & $0.008^{\star *}$ \\
\hline Hydrologic Function & -0.79 & $<0.001^{* *}$ & 0.60 & $<0.001^{\star \star}$ & -0.28 & $0.023^{*}$ \\
\hline Biotic Integrity & 0.32 & $0.005^{\text {** }}$ & -0.08 & 0.514 & 0.00 & 0.995 \\
\hline
\end{tabular}

\footnotetext{
${ }^{1 *}$ indicates correlation significant at the 0.05 probability level; ${ }^{* *}$ indicates correlation significant at the 0.01 probability level.
} 
for measuring the number and extent of rills or the extent of wind erosion and deposition, both of which appear to be important for detecting road impacts. If they can be applied efficiently and consistently, the transect techniques used in this study for measuring the extent of rill and gully development could help to fill this information gap. Furthermore, the quantitative indicators available for assessing surface loss or degradation (subsurface soil aggregate stability) does not measure the thickness of the A horizon and might not be able to detect subtle but important changes in soil structure. Similarly, the suggested methods for measuring the amount of water flow patterns (basal cover and gaps) are not likely to detect important changes in water flow patterns associated with disturbance in communities with naturally low basal cover and large basal gaps (e.g., shrub community in New Mexico). The lack of quantitative indicators for some IIRH indicators and possibly low sensitivity of others suggest that new quantitative measures sensitive to abiotic changes associated with rill and inter-rill erosion should be developed.

\section{Application of IIRH for Assessment of Linear Features}

To differentiate impacts of roads, off-highway vehicle trails, and energy development from other stressors such as grazing and climate with IIRH, it is necessary to conduct IIRH assessments both in areas impacted by activity of concern and in areas not impacted by activity of concern (control area). This could be accomplished using a paired approach, as was done in this study, or as a separate random selection of plots. However, because ecological sites often include some variability in soils and landscape positions, if the latter (nonpaired control) approach is used, it is important that the IIRH assessments account for within ecological site variability that influence ecological potential (e.g., slope, aspect, and soil texture). Creating or obtaining a detailed reference sheet that accounts for within ecological site variation can help. Also, when conducting IIRH assessments in a very heterogeneous area, such as along a road margin, we found using a site-specific evaluation matrix (Pellant et al. 2005, p. 24) that explicitly accounted for spatial variability in the indicators to be very helpful. Observers likely would have experienced less agreement in rating attributes for the disturbed plots without the ecological site-specific evaluation matrices (Fig. 4).

\section{IMPLICATIONS}

Results from this study indicate that IIRH is well suited and can be consistently applied for detecting areas adversely impacted by multiple stressors, including off-highway vehicle use and energy development, and has the potential to provide information on cumulative impacts. Because IIRH assessments are potentially a low-precision measurement (low repeatability over time with a variety of observers), they should not be used for monitoring. However, the integration of multiple observational indicators often allows IIRH to more accurately define the current status of the system, especially in aspects that are hard to measure quantitatively such as soil degradation and erosion. To address cumulative effects, it is likely necessary to extrapolate plot measures to landscape scales using both qualitative and quantitative imagery analysis. Satellite- and airborne-based measurements show promise for tracking changes in extent of transportation networks (Wei et al. 2008; Wang et al. 2009; Fang et al. 2010) and detecting changes in important indicators of ecosystem function such as bare ground (Gill and Phinn 2009) and other biophysical indicators (Zhang and Guo 2008). The qualitative imagery interpretation used in this study was important for finding highly impacted areas that would not have been found using strictly random selection. To scale up measures from plots selected using such qualitative techniques, plot data could be used to train and test qualified individuals' ability to consistently detect problem areas with qualitative imagery interpretation. Quantitative plot data could also be used to validate results of remote sensing imagery analysis. Qualitative and quantitative image analysis, coupled with a landscape scale field sampling design, could then be used to provide information to land managers on the cumulative impacts of linear disturbances on ecological function.

\section{ACKNOWLEDGMENTS}

Many thanks to Michelle Mattocks, Stephanie Baker, and Chandra Tucker for assistance with field work. We would also like to thank local BLM and NRCS staff for assistance with planning and reference sheet development, including David Trujillo, Phil Smith, Shane Green, Dana Truman, Lynn Jackson, Arnie Irwin, Ben Adams, Kay Medders, Steve Hannan, and Janelle Gonzales. We would like to thank Skye Wills, Matt Bowker, Joel Brown, and two anonymous reviewers for their helpful comments.

\section{LITERATURE CITED}

Abella, S. R., J. E. Spencer, J. Hoines, and C. Nazarchyk. 2009. Assessing an exotic plant surveying program in the Mojave Desert, Clark County, Nevada, USA. Environmental Monitoring and Assessment 151:221-230.

BAllEY, R. G. 1993. Bailey ecoregions of the continents (reprojected) from the World Conservation Monitoring Center. Global Ecosystems Database Version 2.0. Boulder, CO, USA: NOAA National Geophysical Data Center.

BELNAP, J. 1995. Surface disturbances: their role in accelerating desertification. Environmental Monitoring and Assessment 37:39-57.

Belnap, J., AND D. A. Gillette. 1997. Disturbance of biological soil crusts: impacts on potential wind erodibility of sandy desert soils in southeastern Utah. Land Degradation \& Development 8:355-362.

Bestelmeyer, B. T. 2006. Threshold concepts and their use in rangeland management and restoration: the good, the bad, and the insidious. Restoration Ecology 14:325-329.

Bird, S. B., J. E. Herrick, M. M. Wander, and L. Murray. 2007. Multi-scale variability in soil aggregate stability: implications for understanding and predicting semiarid grassland degradation. Geoderma 140:106-118.

[BLM] Bureau of Land Management. 2003. Chapter 2-public participation, issue identification, and alternatives. In: Final environmental impact statement and proposed plan amendment for the Powder River Basin oil and gas project. Buffalo, WY, USA: US Department of the Interior, Bureau of Land Management, Wyoming State Office. p. 2-1-2-87.

Bolling, J. D., and L. R. Walker. 2000. Plant and soil recovery along a series of abandoned desert roads. Journal of Arid Environments 46:1-24.

Brooks, M. L., AND B. LAIR. 2005. Ecological effects of vehicular routes in a desert ecosystem. Las Vegas, NV, USA: US Department of the Interior, Geological Survey, Western Ecological Research Center. 23 p.

Brown, D. G., K. M. Johnson, T. R. Loveland, and D. M. Theobald. 2005. Rural landuse trends in the conterminous United States, 1950-2000. Ecological Applications 15:1851-1863.

Chaudhary, V. B., M. A. Bowker, T. E. O’Dell, J. B. Grace, A. E. Redman, M. C. Rillig, AND N. C. Johnson. 2009. Untangling the biological contributions to soil stability in semiarid shrublands. Ecological Applications 19:110-122. 
Cordell, H. K., C. J. Betz, G. Green, and M. Owens. 2005. Off-highway vehicle recreation in the United States, regions and states: a national report from the National Survey on Recreation and the Environment (NSRE). Athens, GA, USA: US Department of Agriculture, Forest Service, Southern Research Station. $86 \mathrm{p}$.

Evans, R. A., AND R. M. Love. 1957. The step-point method of sampling: a practical tool in range research. Journal of Range Management 10:208-212.

Fang, S., G. Z. Gertner, A. B. Anderson, H. R. Howard, P. Sullivan, and C. Otto. 2010. Prediction and uncertainty source analysis of the spatial and temporal disturbance from off-road vehicular traffic in a complex ecosystem. Journal of Environmental Management 91:772-780.

Fang, S. F., S. Wente, G. Z. Gertner, G. X. Wang, and A. Anderson. 2002. Uncertainty analysis of predicted disturbance from off-road vehicular traffic in complex landscapes at Fort Hood. Environmental Management 30:199-208.

Fleischner, T. L. 1994. Ecological costs of livestock grazing in western North America. Conservation Biology 8:629-644.

Forman, R. T. T., and L. E. Alexander. 1998. Roads and their major ecological effects. Annual Review of Ecology and Systematics 29:207-231.

Fuchs, E. H., M. K. Wood, T. L. JoNES, AND B. Racher. 2003. Impacts of tracked vehicles on sediment from a desert soil. Journal of Range Management 56:342-352.

Gelbard, J. L., And J. Belnap. 2003. Roads as conduits for exotic plant invasions in a semiarid landscape. Conservation Biology 17:420-432.

GelıIs, A. C. 1996. Gullying at the Petroglyph National Monument, New Mexico. Journal of Soil and Water Conservation 51:155-159.

GILL, T. K., AND S. R. PhinN. 2009. Improvements to Aster-derived fractional estimates of bare ground in a savanna rangeland. IEEE Transactions on Geoscience and Remote Sensing 47:662-670.

Graves, P., A. Atkinson, and M. Goldback. 2006. Travel and transportation management: planning and conducting route inventories. Technical reference 9113-1. Denver, C0, USA: Bureau of Land Management. $51 \mathrm{p}$.

GRISMER, M. E. 2007. Soil restoration and erosion control: quantitative assessment and direction. Transactions of the ASABE 50:1619-1626.

Hansen, A. J., R. Rasker, B. Maxwell, J. J. Rotella, J. D. Johnson, A. W. Parmenter, L. Langner, W. B. Cohen, R. L. Lawrence, and M. P. V. Kraska. 2002. Ecological causes and consequences of demographic change in the New West. Bioscience 52:151-162.

Herrick, J. E., B. T. Bestelmeyer, S. Archer, A. J. Tugel, and J. R. Brown. 2006a. An integrated framework for science-based arid land management. Journal of Arid Environments 65:319-335.

HERRICK, J. E., AND T. L. JonEs. 2002. A dynamic cone penetrometer for measuring soil penetration resistance. Soil Science Society of America Journal 66:1320-1324.

Herrick, J. E., G. E. Schuman, and A. Rango. 2006b. Monitoring ecological processes for restoration projects. Journal of Nature Conservation 14:161-171.

Herrick, J. E., J. W. Van Zee, K. M. Havstad, L. M. Burkett, and W. G. Whitford. 2005. Monitoring manual for grassland, shrubland and savanna ecosystems. Volume I. Tucson, AZ, USA: University of Arizona Press. 36 p.

Herrick, J. E., W. G. Whitford, A. G. de Soyza, J. W. Van Zee, K. M. Havstad, C. A. Seybold, and M. Walton. 2001. Soil aggregate stability kit for field-based soil quality and rangeland health evaluations. Catena 44:27-35.

Iverson, R. M. 1980. Processes of accelerated pluvial erosion on desert hillslopes modified by vehicular traffic. Earth Surface Processes 5:369-388.

KING, E. G., AND R. J. HoBBS. 2006. Identifying linkages among conceptual models of ecosystem degradation and restoration: towards an integrative framework. Restoration Ecology 14:369-378.

LEI, S. A. 2004. Soil compaction from human trampling, biking, and off-road motor vehicle activity in a blackbrush (Coleogyne ramosissima) shrubland. Western North American Naturalist 64:125-130.

Leu, M., S. E. Hanser, And S. T. KNick. 2008. The human footprint in the west: a large-scale analysis of anthropogenic impacts. Ecological Applications 18:1119-1139.

LI, J. R., G. S. Okin, L. J. Alvarez, and H. E. Epstein. 2009. Sediment deposition and soil nutrient heterogeneity in two desert grassland ecosystems, southern New Mexico. Plant and Soil 319:67-84.

Lovich, J. E., AND D. BainBridge. 1999. Anthropogenic degradation of the southern California desert ecosystem and prospects for natural recovery and restoration. Environmental Management 24:309-326.
Mack, R. N., And J. N. Thompson. 1982. Evolution in steppe with few large, hooved mammals. American Naturalist 119:757-773.

McCune, B., And M. J. MefFord. 2006. PC-ORD. Multivariate analysis of ecological data. Version 5.10. Gleneden Beach, OR, USA: MjM Software.

Milıer, M. E. 2008. Broad-scale assessment of rangeland health, Grand StaircaseEscalante National Monument, USA. Rangeland Ecology and Management 61:249-262.

Pellant, M., P. Shaver, D. Pyke, and J. Herrick. 2005. Interpreting indicators of rangeland health. Version 4.0. Denver, CO, USA: Bureau of Land Management. $122 \mathrm{p}$.

Pyke, D. A., J. E. Herrick, P. Shaver, and M. Pellant. 2002. Rangeland health attributes and indicators for qualitative assessment. Journal of Range Management 55:584-597.

ReiJnen, R., R. Foppen, and G. Veenbaas. 1997. Disturbance by traffic of breeding birds: evaluation of the effect and considerations in planning and managing road corridors. Biodiversity and Conservation 6:567-581.

SAS InStitute. 2001. The SAS system for Windows 8.02. Cary, NC, USA: SAS Institute Inc.

Theobald, D. M. 2001. Land-use dynamics beyond the American urban fringes. Geographical Review 91:544-564

Theobald, D. M., J. R. MılleR, and N. T. Hobbs. 1997. Estimating the cumulative effects of development on wildlife habitat. Landscape and Urban Planning 39:25-36.

Thurow, T. L., S. D. Warren, and D. H. Carlson. 1993. Tracked vehicle effects on the hydrologic characteristics of central Texas rangeland. Transactions of the ASAE 36:1645-1650.

Treweek, J. R., P. Hankard, D. B. Roy, H. Arnold, and S. Thompson. 1998. Scope for strategic ecological assessment of trunk-road development in England with respect to potential impacts on lowland heathland, the Dartford warbler (Sy/via undata) and the sand lizard (Lacerta agilis). Journal of Environmental Management 53:147-163.

[USDA-NRCS] US Department of Agriculture, Natural Resources Conservation SERVICE. 2002. Major Land Resource Area (MLRA) boundaries for the conterminous United States. Available at: http://www.nrcs.usda.gov/technical/ $\mathrm{NRI} /$ maps/aboutmaps/us48mlra.html. Accessed 24 November 2008.

[USDA-NRCS] US Department of Agriculture, Natural Resources Conservation Service. 2003. Ecological site information system. Available at: http://esis.sc. egov.usda.gov/. Accessed 20 April 2009.

Vias, A. C., AND J. I. Carruthers. 2005. Regional development and land use change in the rocky mountain west, 1982-1997. Growth and Change 36:244-272.

Wang, G., G. Z. Gertner, A. B. Anderson, and H. Howard. 2009. Simulating spatial pattern and dynamics of military training impacts for allocation of land repair using images. Environmental Management 44:810-823.

Watts, R. D., R. W. Compton, J. H. McCammon, C. L. Rich, S. M. Wright, T. Owens, AND D. S. OUREN. 2007. Roadless space of the conterminous United States. Science 316:736-738.

WEBB, R. H. 1983. Compaction of desert soils of off-road vehicles. In: R. H. Webb and H. G. Wilshire [EDS.]. Environmental effects of off-road vehicles. New York, NY, USA: Springer. p. 52-78.

Wel, O. Y., F. H. HaO, Y. S. Fu, and J. X. Zhang. 2008. Desert disturbance assessments of regional oil exploitation by ASTER and ETM Plus images in Taklimakan Desert China. Environmental Monitoring and Assessment 144:159-168.

WiLlams, S. M. 2003. Tradition and change in the sub-arctic: Sami reindeer herding in the modern era. Scandinavian Studies 75:229-256.

Yorks, T. P., N. E. West, R. J. Mueller, and S. D. Warren. 1997. Toleration of traffic by vegetation: life form conclusions and summary extracts from a comprehensive data base. Environmental Management 21:121-131.

Zhang, C., And X. Guo. 2008. Monitoring northern mixed prairie health using broadband satellite imagery. International Journal of Remote Sensing 29:2257-2271.

Ziegleg, A. D., T. W. Giambelluca, and R. A. Sutherland. 2002. Improved method for modelling sediment transport on unpaved roads using KINEROS2 and dynamic erodibility. Hydrologic Processes 16:3079-3089. 